Annals of Pure and Applied Mathematics

Vol. 15, No. 2, 2017, 185-192

ISSN: 2279-087X (P), 2279-0888(online)

Published on 11 December 2017

www.researchmathsci.org

DOI: http://dx.doi.org/10.22457/apam.v15n2a4

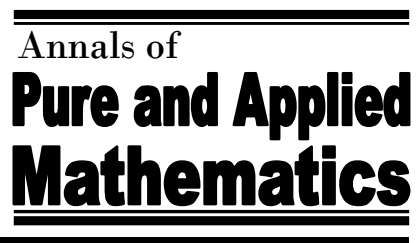

\title{
Paradox in a Linear Multi Objective Transportation Problem
}

\author{
R. Sophia Porchelvi ${ }^{1}$ and M. Anitha ${ }^{2}$ \\ A.D.M. College for Women (Autonomous) \\ Nagapattinam-611 001, Tamil Nadu, India \\ 11Email: sophiaporchelvi@gmail.com; ${ }^{2}$ Email: anithamscmphil@ gmail.com
}

Received 1 November 2017; accepted 9 December 2017

\begin{abstract}
In this paper, an algorithm is developed to find the paradoxical solution of multi objective transportation problem with linear constraints. It also attempts to obtain its best paradoxical pair and paradoxical range of flow by using the sufficient condition of the existing paradox. Numerical illustration is also provided to check the feasibility.
\end{abstract}

Keywords: Northwest corner method, Multi objective transportation problem, Paradoxical pair, Paradoxical range of flow.

AMS Mathematics Subject Classification (2010): 90C08

\section{Introduction}

The term Paradox arises when a transportation problem admits a total cost which is lower than the optimum. This is attainable by shipping larger quantities of goods over the same routes that were previously chosen as optimal which is unusual phenomenon noted by Szwarc (1971). The classical transportation problem is the name of a mathematical model has a special mathematical structure. The mathematical formulation of a large number of problems conforms to this special structure. Hitchcock (1941) originally developed the basic linear transportation problem. Klingman and Russel (1974 and 1975) introduced a specialized method for solving a transportation problem with several additional linear constraints. Hadley (1987) gave the detailed solution procedure for solving linear transportation problem. Till date, several researchers studied comprehensively to solve transportation problem cost minimizing its cost in various ways.

In some situations, if we obtain more flow with lesser cost than the flow corresponding to the optimum cost then we say paradox occurs. Charnes and Klingman (1971), Szwarc (1973), Adlakha and Kowalski (1998) and Storoy (2007) considered the paradoxical transportation problem. Gupta et al (1993) considered a paradox in linear fractional transportation problem with mixed constraints. Joshi and Gupta (2010) studied paradox in linear plus fractional transportation problem. Basu, Acharya and Das (2012) developed an algorithm for finding all paradoxical pairs in a linear transportation problem. Acharya, Basu and Das(2015), discussed more-for-less paradox in a transportation problem under fuzzy environment with linear constraints. Sophia Porchelvi and Anna Sheela (2015) developed an algorithm to find linear multi-objective fractional transportation problem and its paradoxical solution. 


\section{R. Sophia Porchelvi and M. Anitha}

This Paper is organized as follows: In Section 2 Basic Definitions are given. Section 3 explains the mathematical formulation and sufficient condition for the existence of paradox of linear Multi objective transportation problem. In Section 4, an Algorithm is developed to solve linear Multi objective transportation problem. In Section 5, a Numerical Example is given to show the optimal solution of linear Multi objective transportation problem. In that solution, the paradoxical range of the flow and the best paradoxical pair is found. The conclusion of the paper is given in Section 6.

\section{Preliminaries}

Paradox in a transportation problem: In a transportation problem if we can obtain more flow $\left(\mathrm{F}^{1}\right)$ with lesser cost $\left(\mathrm{Z}^{1}\right)$ than the optimum flow $\left(\mathrm{F}^{0}\right)$ corresponding to the optimum cost $\left(Z^{0}\right)$ i.e. $F^{1}>F^{0}$ and $Z^{1}<Z^{0}$, then we say that a paradox occurs in a transportation problem.

2. Cost-flow pair: If the value of the objective function is $Z^{0}$ and the flow is $\mathrm{F}^{0}$ corresponding to the feasible solution $\mathrm{X}^{0}$ of a transportation problem, then the pair corresponding to the feasible solution $\mathrm{X}^{0}$.

3. Paradoxical pair: A cost-flow pair, $(\mathrm{Z}, \mathrm{F})$ of an objective function is called paradoxical pair if $Z<Z^{0}$ and $F>F^{0}$ where $Z^{0}$ is the optimum cost and $\mathrm{F}^{0}$ is the optimum flow of the transportation problem.

4. Best paradoxical pair: The paradoxical pair $\left(Z^{*}, F^{*}\right)$ is called the best paradoxical pair of a transportation problem if for all paradoxical pair $(Z, F)$, either $Z^{*}<Z$ or $Z^{*}=Z$ but $F^{*}>F$.

5. Paradoxical range of flow: If $\mathrm{F}^{0}$ be the optimum flow and $\mathrm{F}^{*}$ be the flow corresponding to the best paradoxical pair of a transportation problem then $\left[\mathrm{F}^{0}, \mathrm{~F}^{*}\right]$ is called paradoxical range of flow.

\section{Mathematical formulation}

Consider the following linear Multi-Objective Transportation problem (LMOTP)

$\left(\mathrm{P}^{1}\right)$ : Minimize $\mathrm{Z}=\left\{\sum_{(i, j) \in J} C_{i j}^{l} x_{i j,} \sum_{(i, j) \in J} C_{i j}^{2} x_{i j}, \cdots \cdots \sum_{(i, j) \in J} C_{i j}^{k} x_{i j}\right\}$

Subject to $\sum_{j \in N} X_{i j}=a_{i}, \mathrm{i} \in M$

$\sum_{i \in m} X_{i j}=b_{j}, \mathrm{j} \in N$

$\mathrm{X}_{\mathrm{ij}} \geq 0 \forall(i, j) \in J$

where $a_{i}$ is the $i^{\text {th }}$ source, $b_{j}$ is the $j^{\text {th }}$ destination

$\mathrm{X}_{\mathrm{ij}}=$ the amount transported from the $\mathrm{i}^{\mathrm{th}}$ source to the $\mathrm{j}^{\text {th }}$ destination.

$\mathrm{C}_{\mathrm{ij}}^{\mathrm{l}}=$ the cost per unit amount transported from $\mathrm{i}^{\mathrm{th}}$ source to the destination corresponding to $\mathrm{k}$ objectives. i.e. $\mathrm{l}=1,2,3, \ldots \mathrm{k}$.

In this paper we assume that $\mathrm{a}_{\mathrm{i}}>0, \mathrm{i} \in M$ and $b_{j}>0, \mathrm{j} \in N$ and $\sum_{j=1}^{n} X_{i j}=a_{i}, \sum_{i=1}^{m} X_{i j}=b_{j}$, Let $\mathrm{X}^{0}=\left\{X_{i j}^{0} \backslash(\mathrm{i}, \mathrm{j}) \in \mathrm{I} \times \mathrm{J}\right\}$ be a basic feasible solution corresponding to the basis $\mathrm{B}$ of the problem $\mathrm{P}^{1}$ and the value of the objective function $\mathrm{Z}^{1,2, \ldots . . \mathrm{k}}$ corresponding to the basic feasible solution $\mathrm{X}^{0}$ is given below.

$\mathrm{Z}^{1}=\sum_{(i, j) \in J} C_{i j}^{l} x_{i j}, \mathrm{Z}^{2}=\sum_{(i, j) \in J} C_{i j}^{2} x_{i j}, \ldots \ldots \ldots \mathrm{Z}^{\mathrm{k}}=\sum_{(i, j) \in J} C_{i j}^{k} x_{i j}$ 


\section{Paradox in a Linear Multi Objective Transportation Problem}

Let $\mathrm{F}^{0}$ be the corresponding flow.

Then $\mathrm{F}^{0}=\sum_{i \in I} a_{i}=\sum_{j \in I} b_{j}$.

Let $\left(\mathrm{U}^{\mathrm{L}}{ }_{\mathrm{i}}, \mathrm{V}^{\mathrm{L}} \mathrm{j}\right),(\mathrm{L}=1,2,3 \ldots . \mathrm{k})$ be the corresponding dual variable associated with the above k problems $\left(\mathrm{P}^{\mathrm{l}}\right)$, so that $\mathrm{U}_{\mathrm{i}}^{\mathrm{L}}+\mathrm{V}^{\mathrm{L}}{ }_{\mathrm{j}}=\mathrm{C}^{\mathrm{L}} \mathrm{ij}$ for $(\mathrm{i}, \mathrm{j}) \notin \mathrm{B} \forall \mathrm{L}=1,2,3, \ldots . \mathrm{k}$.

$$
\text { Let } \mathrm{C}^{\mathrm{L}} \mathrm{ij}=\left(\mathrm{U}_{\mathrm{i}}^{\mathrm{L}}+\mathrm{V}^{\mathrm{L}}{ }_{\mathrm{j}}\right)-\mathrm{C}_{\mathrm{ij}}
$$

If $\mathrm{C}^{\mathrm{L}}{ }_{\mathrm{ij}}<0$ for $(\mathrm{i}, \mathrm{j}) \notin \mathrm{B} \forall \mathrm{L}=1,2,3, \ldots \mathrm{k}$, then the solution is optimal.

Theorem 1. The sufficient condition for the existence of paradoxical solution of $\left(\mathrm{P}^{1}\right)$ is that if $\exists$ at least one cell $(r, s) \notin B$ in the optimum table of $\left(\mathrm{P}^{1}\right)$ where $a_{r} a n d b_{s}$ are replaced by $\mathrm{a}_{\mathrm{r}}+1$ and $\mathrm{b}_{\mathrm{s}}+1$ respectively $(1>0)$ then $\left(\mathrm{U}_{\mathrm{i}}^{\mathrm{L}}+\mathrm{V}_{\mathrm{i}}^{\mathrm{L}}\right)<0, \mathrm{~L}=1,2,3 \ldots \mathrm{k}$.

Proof: Let $Z^{1,2, \ldots . k}$ be the value of the objective function and $F^{1,2,3 \ldots k}$ be the optimum flow corresponding to the optimum solution $\mathrm{X}^{1,2,3, \ldots \mathrm{k}}$ of problem $\mathrm{P}^{1}$. The dual variables $\mathrm{U}_{\mathrm{i}}^{\mathrm{L}}$ and $\mathrm{V}_{\mathrm{i}}^{\mathrm{L}}$ are given by

$\mathrm{U}_{\mathrm{i}}^{\mathrm{L}}+\mathrm{V}_{\mathrm{i}}^{\mathrm{L}}=\mathrm{C}_{\mathrm{ij}},(\mathrm{i}, \mathrm{j}) \in \mathrm{J}$

Then, $\mathrm{Z}^{1}=\sum_{(i, j) \in J} C_{i j}^{l} x_{i j}, \mathrm{Z}^{2}=\sum_{(i, j) \in J} C_{i j}^{2} x_{i j}, \ldots \ldots \ldots \mathrm{Z}^{\mathrm{k}}=\sum_{(i, j) \in J} C_{i j}^{k} x_{i j}$

and $\mathrm{F}^{0}=\sum_{i=1}^{m} a_{i}=\sum_{j=1}^{n} b_{j}$

Now, let $\exists$ at least one cell $(r, s) \notin B$, where $a_{r}$ and $b_{s}$ are replaced by $a_{r}+1$ and $b_{s}+1$ respectively $(1>0)$ in such a way that the optimum basis remains same, then the value of the objective function $\mathrm{Z}$ is given by

$\mathrm{Z}=\left[\mathrm{Z}^{0}+1\left(\mathrm{U}_{\mathrm{i}}^{\mathrm{L}}+\mathrm{V}_{\mathrm{i}}^{\mathrm{L}}\right)\right]$

The new flow $\mathrm{F}$ is given by

$\mathrm{F}=\sum_{i=1}^{m} a_{i}+1=\sum_{j=1}^{n} b_{j}+1=\mathrm{F}^{0}+1$

$\mathrm{F}-\mathrm{F}^{0}=1>0$

Therefore, for the existence of paradox we must have $\mathrm{Z}-\mathrm{Z}^{1,2,3, \ldots \mathrm{k}}<0$. Hence the sufficient condition for the existence of paradox is that $\exists$ at least one cell $(\mathrm{r}, \mathrm{s}) \notin \mathrm{B}$ in the optimum table such that if $a_{r}$ and $b_{s}$ are replaced by $a_{r}+1$ and $b_{s}+1$ respectively.

Then $(1>0)$ then $1\left(\mathrm{U}_{\mathrm{i}}^{\mathrm{L}}+\mathrm{V}_{\mathrm{i}}^{\mathrm{L}}\right)<0, \mathrm{~L}=1,2,3 \ldots \mathrm{k}$.

(i.e) $\left(\mathrm{U}_{\mathrm{i}}^{\mathrm{L}}+\mathrm{V}_{\mathrm{i}}^{\mathrm{L}}\right)<0$, the solution is optimal.

\section{Algorithm for solving linear multi objective transportation problem}

Step 1: Find the cost-flow pair $\left(\mathrm{Z}^{\mathrm{i}}, \mathrm{F}^{\mathrm{i}}\right)$ for the optimum solution $\mathrm{X}^{0},(\mathrm{i}=1,2,3, \ldots . . \mathrm{k})$

Step 2: Fix i=1

Step 3: Find all cells where $(r, s) \notin B$ such that $\left(U_{r}+V_{s}\right)<0$ if it exists otherwise go to step 8.

Step 4: Among all cells (r, s) $\notin B$ satisfying step 3 find min flow for $1=1$ which enter into the existing basis whose corresponding cost is minimum. Let $\left(\mathrm{Z}^{\mathrm{i}}, \mathrm{F}^{\mathrm{i}}\right)$ be the new cost flow pair corresponding to the optimum solution $\mathrm{X}^{\mathrm{j}}(\mathrm{j}=1,2, \ldots \mathrm{k})$

Step 5: Write $\left(Z^{j}, F^{j}\right)$.

Step 6: By re-fixing $\mathrm{i}=\mathrm{i}+1$ 


\section{R. Sophia Porchelvi and M. Anitha}

Step 7: Repeat the procedure goto step 3.

Step 8: We write the best paradoxical pair $\left(\mathrm{Z}^{*}, \mathrm{~F}^{*}\right)=\left(\mathrm{Z}^{\mathrm{j}}, \mathrm{F}^{\mathrm{j}}\right)$ for the optimum solution $\mathrm{X}^{*}$ $=\mathrm{X}^{\mathrm{j}}$.

Step 9: Finding the paradoxical solution, end at this stage.

\section{Numerical illustration}

Consider the following Multi objective linear transportation problem using the numerical values, as tabulated below:

Table 1:

\begin{tabular}{|c|c|c|c|c|c|}
\hline & $\mathrm{D}_{1}$ & $\mathrm{D}_{2}$ & $\mathrm{D}_{3}$ & $\mathrm{D}_{4}$ & $\mathrm{a}_{\mathrm{i}}$ \\
\hline $\mathrm{O}_{1}$ & 4 & 10 & 11 & 35 & \\
& 1 & 9 & 9 & 27 & 20 \\
& 1 & 6 & 6 & 20 & \\
\hline & 38 & 25 & 10 & 49 & \\
$\mathrm{O}_{2}$ & 32 & 22 & 6 & 42 & 10 \\
& 5 & 2 & 13 & 15 & \\
& & & & & \\
\hline $\mathrm{O}_{3}$ & 19 & 8 & 25 & 35 & \\
& 6 & 2 & 22 & 28 & 15 \\
\hline $\mathrm{O}_{4}$ & 17 & 1 & 10 & 11 & \\
& 6 & 5 & 6 & 7 & 35 \\
& 6 & 2 & 4 & 3 & \\
\hline $\mathrm{b}_{\mathrm{j}}$ & 25 & 25 & 15 & 15 & \\
\hline
\end{tabular}

Solving the above problem using the Northwest corner method, the optimal Multi objective transportation table is presented in Table II.

Table II:

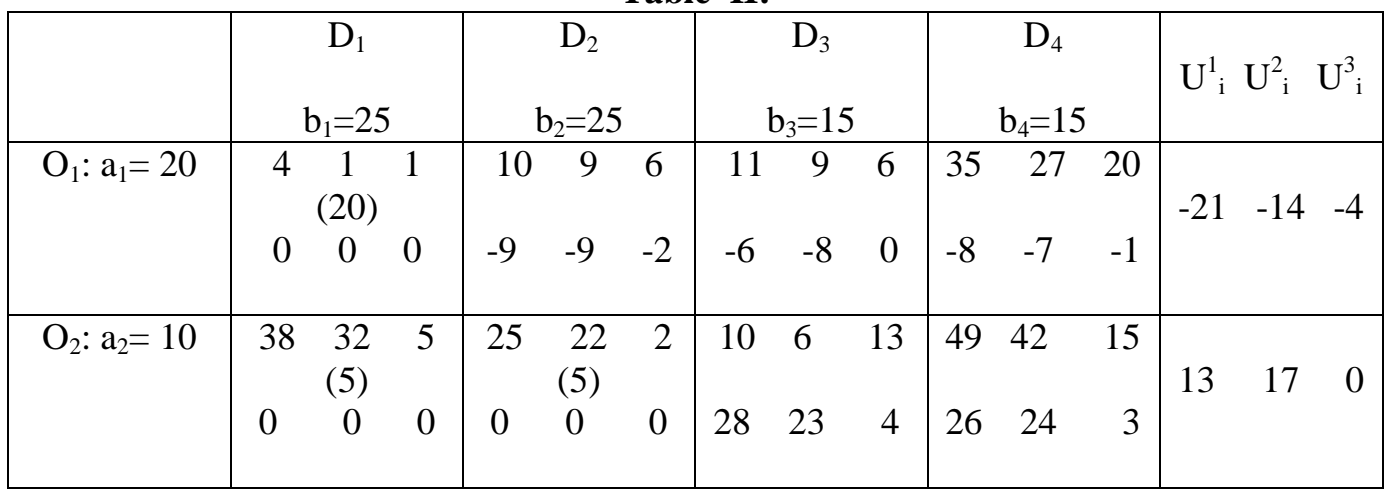


Paradox in a Linear Multi Objective Transportation Problem

\begin{tabular}{|c|c|c|c|c|c|c|c|c|c|c|c|c|c|c|c|}
\hline $\mathrm{O}_{3}: \mathrm{a}_{3}=15$ & $\begin{array}{l}19 \\
21\end{array}$ & $\begin{array}{r}17 \\
12\end{array}$ & 6 & $\begin{array}{l}8 \\
0\end{array}$ & $\begin{array}{c}2 \\
(15) \\
0\end{array}$ & 0 & $\begin{array}{l}25 \\
11\end{array}$ & 22 & 10 & 9 & $\begin{array}{l}28 \\
4\end{array}$ & $\begin{array}{r}11 \\
2\end{array}$ & -4 & -3 & -1 \\
\hline $\mathrm{O}_{4}: \mathrm{a}_{4}=35$ & $\begin{array}{l}10 \\
25\end{array}$ & $\begin{array}{l}6 \\
15\end{array}$ & 5 & $\begin{array}{c}12 \\
0\end{array}$ & $\begin{array}{c}5 \\
(5) \\
0\end{array}$ & 0 & $\begin{array}{l}15 \\
0\end{array}$ & $\begin{array}{c}6 \\
(15) \\
0\end{array}$ & 0 & 13 & $\begin{array}{c}7 \\
(15) \\
0\end{array}$ & $\begin{array}{l}3 \\
0\end{array}$ & 0 & 0 & 0 \\
\hline $\begin{array}{l}V^{1}{ }_{j} \\
V^{2}{ }_{j} \\
V^{3}{ }_{j}\end{array}$ & & $\begin{array}{c}25 \\
15 \\
5\end{array}$ & & & $\begin{array}{l}5 \\
2\end{array}$ & & & $\begin{array}{l}6 \\
4\end{array}$ & & & $\begin{array}{c}13 \\
7 \\
3\end{array}$ & & & & \\
\hline
\end{tabular}

For this solution is $X=\{20,0,0,0,5,5,0,0,0,5,0,0,0,5,15,15\}$ for which $Z=$ $(995,540,185), Z_{1}=995, Z_{2}=540, Z_{3}=185$.

When we check the sufficient condition for the existence of paradoxical solution $\left(U_{r}+V_{s}\right)$ where(r, s) $\nexists \mathrm{B}$ in Table 1, we observe that for $\mathrm{Z}^{1}$, a paradox occurs in the cell $(1,2)(1,3)(1,4)$ but not in $(2,3),(2,4),(3,1),(3,3),(3,4),(4,1)$.

Next $Z^{2}$, a paradox occurs in the cell $(1,2)(1,3)(1,4)$ but not in $(2,3),(2,4),(3,1),(3,3)$, $(3,4),(4,1)$.

Next $Z^{3}$, a paradox occurs in the cell $(1,2),(1,4)$ but not in $(1,3),(2,3),(2,4),(3,1),(3,3)$, $(3,4)$ and $(4,1)$.

Hence $Z^{1}, Z^{2}, Z^{3}$ the paradox occurs commonly in the cell $(1,2)$ and $(1,4)$.

Applying Step 1: The cost flow pair is $(995,540,185)(80,80,80)$ corresponding to the optimum solution $X^{0}=\left\{X_{11}=20, X_{21}=5, X_{22}=5, X_{32}=5, X_{42}=5, X_{43}=15, X_{44}=15\right\}$

Step 2: Fix i=1

Step 3: Now check the sign of $U_{r}+V_{s}$ and we obtain for the non-basic cells $(1,2)$ and $(1$, 4), the sign that is negative.

Step 4: Hence consider $l=1$ enters in to the optimum basis for the cell $(1,2)$

Table III:

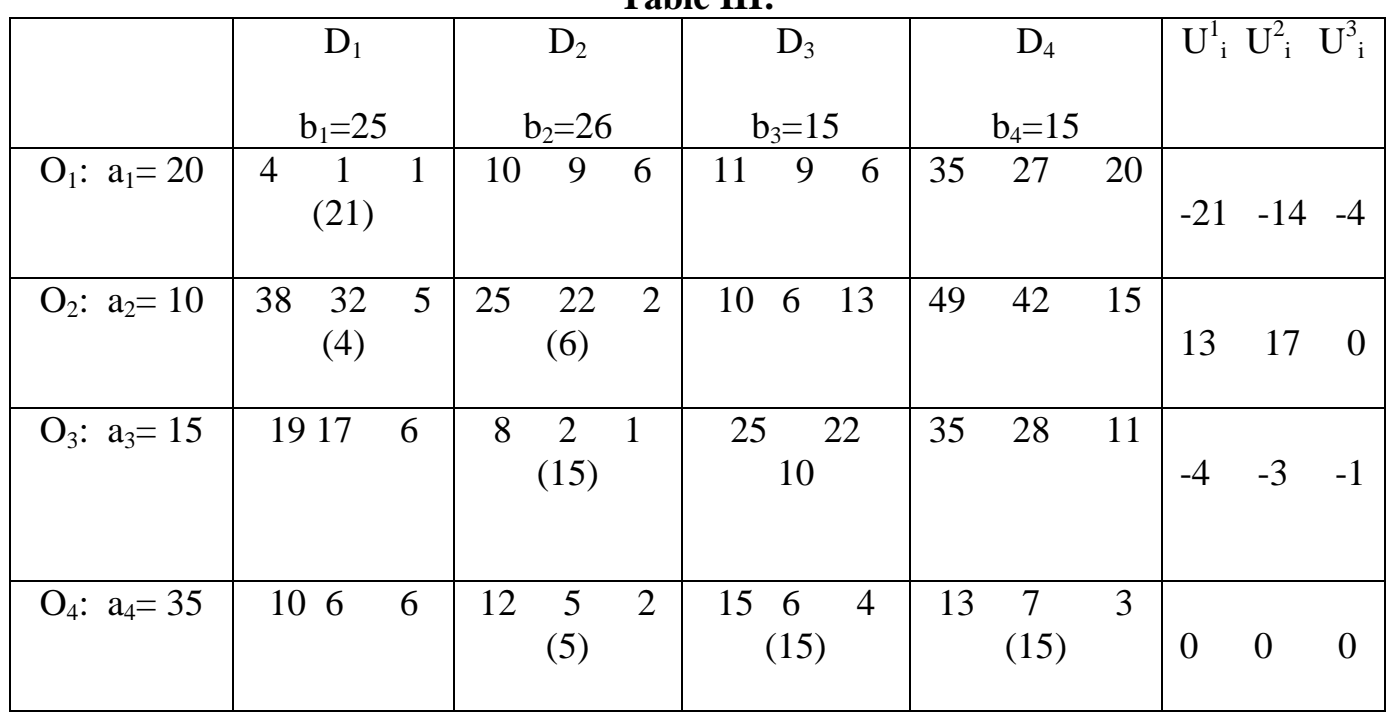


R. Sophia Porchelvi and M. Anitha

\begin{tabular}{|l|c|c|c|c|c|}
\hline $\mathrm{V}^{1}{ }_{\mathrm{j}}$ & 25 & 12 & 15 & 13 & \\
$\mathrm{~V}^{2}{ }_{\mathrm{j}}$ & 15 & 5 & 6 & 7 & \\
$\mathrm{~V}^{3}{ }_{\mathrm{j}}$ & 5 & 2 & 4 & 3 & \\
\hline
\end{tabular}

The corresponding paradoxical pair is $(986,531,183)(81,81,81)$.

For the cell $(1,4)$ Multi objective transportation table is presented in Table IV

Table IV:

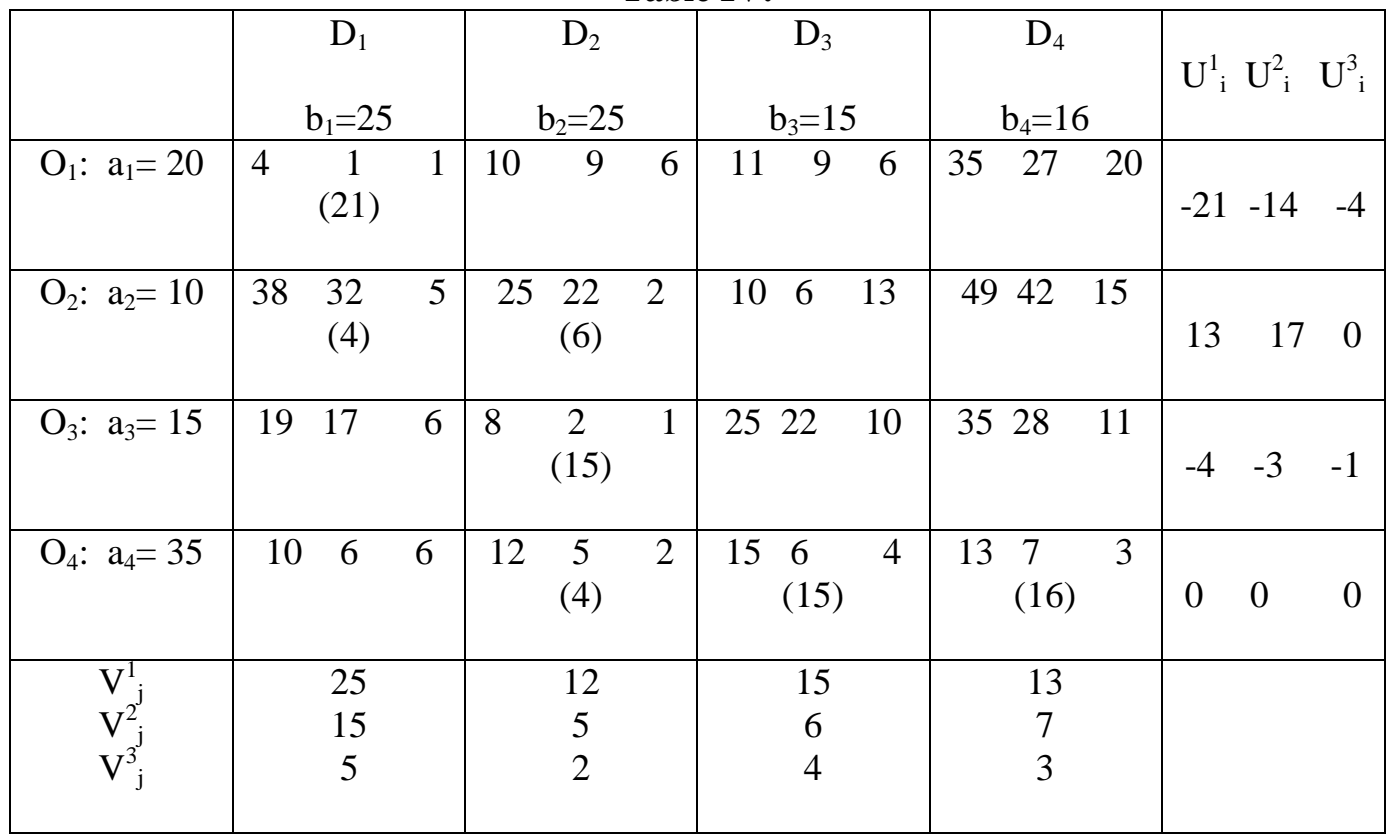

The corresponding paradoxical pair is $(987,533,184)(81,81,81)$

The min cost $=\{(986,531,183),(987,533,183)\}=(986,531,183)$.

Hence $1=1$ enters in the optimum basis from the cell $(1,2)$ and corresponding table is Table IV, the corresponding paradoxical pair is $(986,531,183)(81,81,81)$. Repeating this process in the next table

Table V:

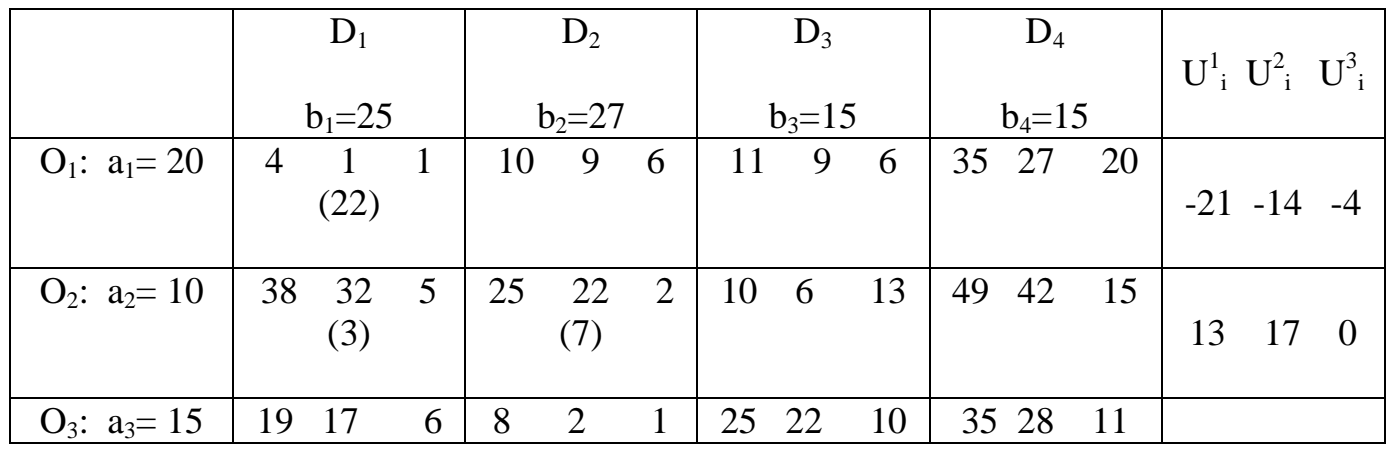


Paradox in a Linear Multi Objective Transportation Problem

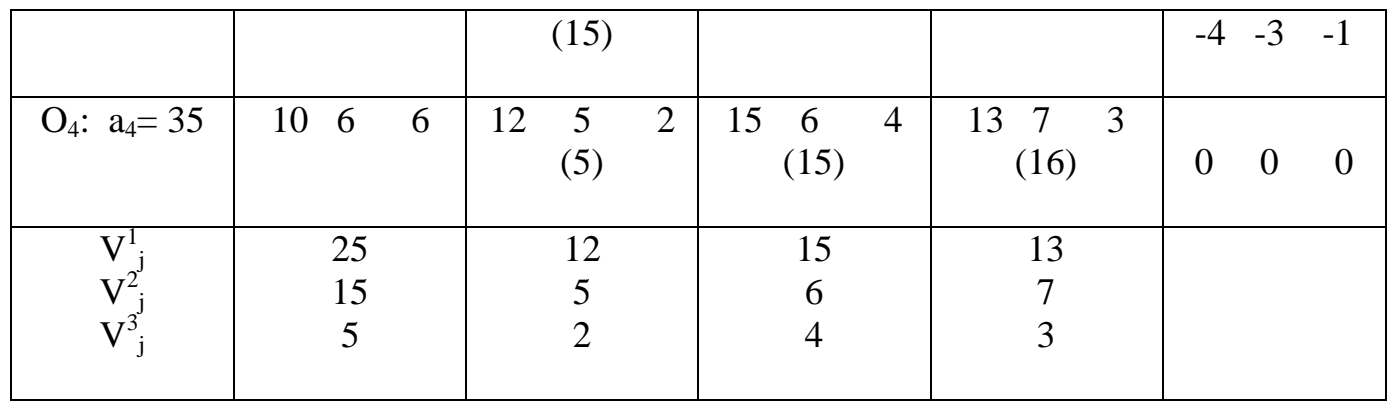

The corresponding paradoxical pair is $(977,522,181)(82,82,82)$

Henceforth from the final Table-VI the best paradoxical pair and the paradoxical range of flow showing an increase in the flow within the value of the objective function, and thus decreases from the optimal solution of the Multi Objective linear transportation problem.

Table VI:

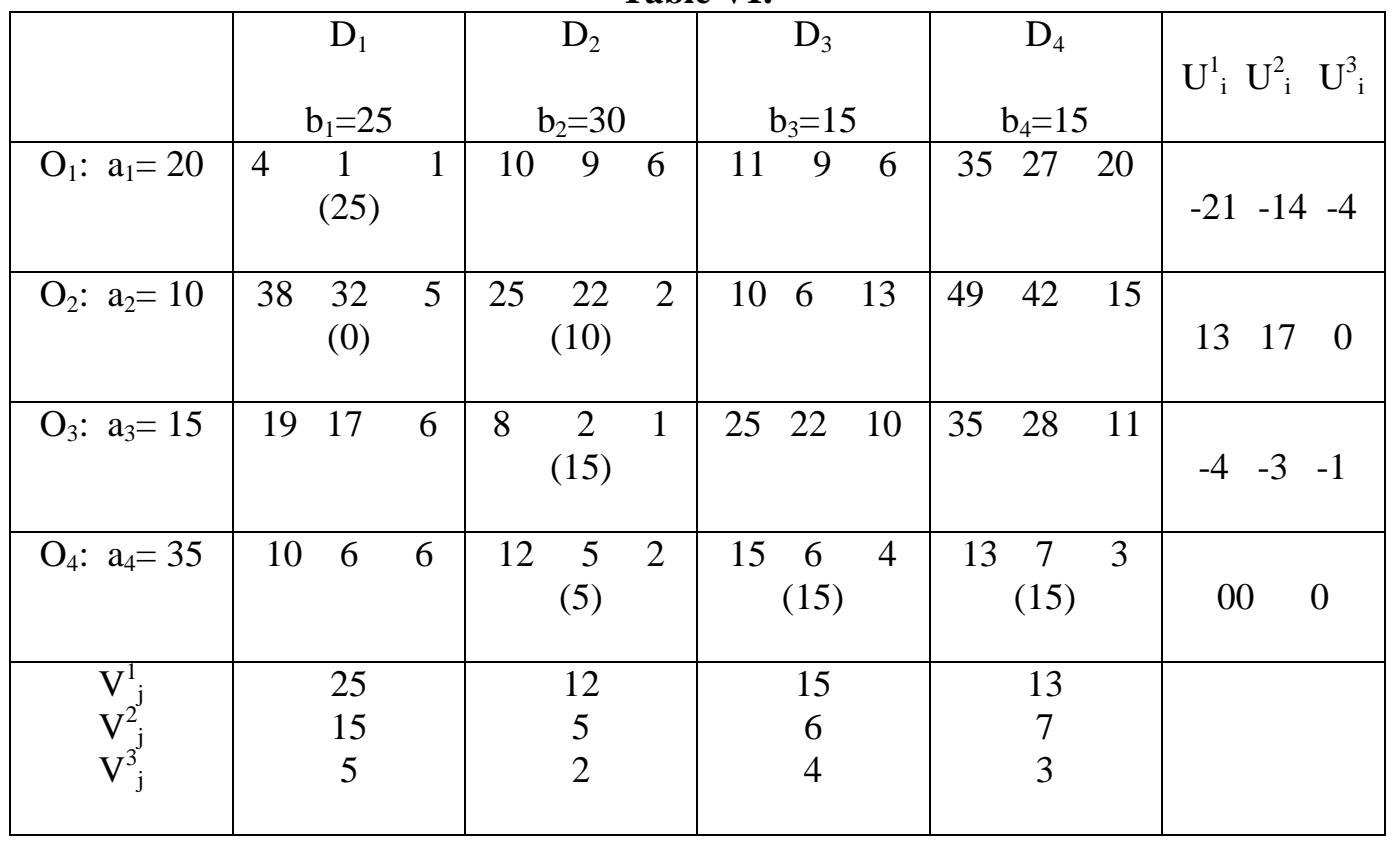

The corresponding paradoxical pair is $(950,495,175)(85,85,85)$

Applying step 8: The best paradoxical pair is $\left(\mathrm{Z}^{*}, \mathrm{~F}^{*}\right)=\{(950,495,175)(85,85,85)\}$. Corresponding to the optimum solution $X^{0}=\left\{X_{11}=25, X_{21}=0, X_{22}=10, X_{32}=15, X_{42}=\right.$ $\left.5, X_{43}=15, X_{44}=15\right\}$ and the paradoxical range of flow is $\left[\mathrm{F}^{0}, \mathrm{~F}^{*}\right]=(80,80,80)(85,85$, $85)$.

\section{Conclusion}

In this paper, a new algorithm is developed to solve the paradoxical solution of linear Multi objective transportation problem. This algorithm gives step by step procedure for the development of finding the best paradoxical pair and a paradoxical range obtained. 


\section{R. Sophia Porchelvi and M. Anitha}

\section{REFERENCES}

1. D.Acharya, M.Basu and M.Das, More-for-less paradox in a transportation problem under fuzzy environments, $J$ Appl Computant Math., 4 (2015) 202.

2. V.Adlakha and K.Kowalski, A quick sufficient solution to the more-for-less paradox in a transportation problem, Omega, 26(4) (1998) 541-547.

3. G.M.Appa, The transportation problem and its variants, Operations Research.Q. 24 (1973) 79-99.

4. M.Basu, D.Acharya and A.Das, The algorithm of finding all paradoxical pair in a linear transportation problem, Discrete Mathematics, Algorithm and Application, 4 (2012) 1250049 (9 pages).

5. A.Charnes and D.Klingman, The more-for-less paradox in the distribution model, Cachiersdu Centre Etudes de Recherche Operaionelle, 13 (1971) 11-22.

6. V.G.Deineko, B.Klinz and G.J.Woeginger, Which matrices re immune against the transportation paradox?, Discrete Applied Mathematics, 130 (2003) 495-501.

7. A.Gupta, S.Khanna and M.C.Puri, A paradox in linear fractional transportation problems with mixed constraints, Optimization, 27 (1993) 375-387.

8. F.L.Hitchcock, The distribution of a product from several resources to numerous localities, Journal of Mathematical Physics, 20 (1941) 224 - 230.

9. V.D.Joshi and N.Gupta, On a paradox in linear plus fractional transportation problem, Mathematika, 26(2) (2010)167-178.

10. S.Storoy, The transportation paradox revisited, N-5020 Bergen, Norway, (2007).

11. W.Szwarc, The transportation paradox, Nav. Res. Logist. Q., 18 (1973) 185-202.

12. D.J.Vishwas and G.Nilama, On a paradox in linear plus linear plus linear fractional transportation problem, Mathematika, 26(2) (2010) 167-178. 